\title{
New Yoruba Idioms and Idiomatic Expressions: A New Mode of Communicating New Concepts and Ideas on Radio
}

Dayo Akanmu*

School of Languages, Adeniran Ogunsanya College of Education, Nigeria

\begin{abstract}
New idioms and idiomatic expressions, which are modern stock expressions, constitute communicative clogs in Yorùbá routine discourses because of their semantic complexity and deviant nature. Existing studies have established their scope of usage in Yorùbá music but have hardly addressed their communicative adaptability in Yorùbá programmes on radio. And in view of the erroneous views of Fakoya and Sunday Sun in its editorial comments of March 28, 2004 that fresh ideas and concepts emanating from globalization/science and technology can hardly be captured by the lexis and structure of Nigerian indigenous languages. This paper investigated issues expressed with these idioms, context and strategies for using them in various Yorùbá programmes on radio. This is with a view to establishing their communicative and stylistic relevance in Yorùbá discourses. The paper adopted Mukarousky's theory of Standard Language because of its capacity to explain the "differential specifica" between the language of everyday interaction and literary language. Six Yorùbá programmes were purposively selected for having sufficient usage of new idioms on these radio stations: 105.6 FM, Lagos; 107.5 FM, Lagos; 92.9 FM, Lagos; 98.5 FM, İbàdàn; 99.2 FM, İbàdàn and 10.55 FM Ìbàdàn. Lagos and Ìbàdàn were chosen based on the urbanised nature of the two cities and constant usage of new idioms on the programmes. Data were subjected to pragmatic and stylistic analyses. In all these, two issues were expressed: globalization and transportation. Globalization, which was peculiar to the electronic media, occurred in the context of mobile phoning/internet while transportation appeared also in electronic media revealing the context of fraud/embezzlement and infrastructure. Nominalisation, compounding and phonoeasthetic coinages were the linguistic strategies employed for the formation of new idioms in this paper. Nominalization and compounding occurred in virtually all the stations; the former was contextualized in advertisement (èrọ-a-yára-bí-àșá) and fraud / embezzlement (ọkọ̣-ọ-rọ-ìbọn-mì) while the latter was in the context of advertisement (itàkùn éétéẹli), political rift/power play politics (itàkùn àgbáyé), information/security (afárá olókè) and executive class (ọbọkún olọyẹ). Phonoeasthetic coinages occurred in the contexts of fraud and information. New idioms and idiomatic expressions, used to express socioeconomic issues in Yorùbá routine communication, occurred in mediated and non-mediated contexts on radio and were conveyed through nominalization, compounding and phonoeasthetic coinages. These idioms reflect dynamism and modernity-constrained stylistic choices in Yorùbá.
\end{abstract}

Keywords: New idioms; Yorùbá programmes; Radio; Globalization linguistic strategies

\section{Introduction}

This paper was motivated by the saying 'the world is a global village' (globalization) which imposes new global communicative challenges on the Yorùbá people especially the radio presenters. The evolution of new idioms and idiomatic expressions thus becomes a coping strategy to meet the new communicative challenges. Globalisation is a phenomenon that filters into all domain of human experiencelinguistic, social, cultural, political or economic. As a result of this, the Yorùbá, like any other people in the Third World countries, are faced with the challenges of how to express their ideas and experiences emanating from globalization. Radio presenters have a duty to inform, enlighten and educate the people about the latest development brought about by the wind of change blowing across the globe. At a time that Nigeria is experiencing innovations in telecommunication which is also useful in sustaining her virgin democratic system of government, the radio presenters cannot afford to be aloof to these global developments.

Another motivation for this paper is the impact it would have on those who think that Yorùbá like other indigenous languages, are restricted to certain domains of usage. For instance, Fákọyà and Sunday Sun in its editorial comments of March 28, 2004 are of the opinion that fresh ideas and concepts emanating from globalization can hardly be captured by the lexis and structure of Nigerian indigenous languages. This opinion is erroneously based on the dominant nature of the English language over Yorùbá and the indiscriminate attitude of the users of the Yorùbá language towards borrowing from the English language. A paper of this nature would not only debunk such erroneous views, but also put the record straight, that even in the process of pedagogy and presentation of programmes on radio, new words are coined to solve linguistic challenges in a way similar to the theory of Ifẹ Six, propounded by the late Professor Babátúndé Fáfúnwá, where it was established that indigenous languages, like Yorùbá are capable of teaching mathematics even better than the English language.

By and large, in this paper, attempt was made to address the issues expressed with new idioms and idiomatic expressions in Yorùbá programmes on radio, contexts and strategies for using them with a view to establishing their communicative and stylistic potential in Yorùbá discourses.

*Corresponding author: Dayo Akanmu, School of Languages, Adeniran Ogunsanya College of Education, Otto/ljanikin, P.M.B 007, Festac Town-Lagos, Nigeria, Tel: +234-01-8506038; E-mail: dayoakanmu2002@yahoo.com

Received October 28, 2014; Accepted November 27, 2014; Published January 01,2015

Citation: Akanmu D (2015) New Yoruba Idioms and Idiomatic Expressions: A New Mode of Communicating New Concepts and Ideas on Radio. J Mass Communicat Journalism 5: 236. doi:10.4172/2165-7912.1000236

Copyright: (c) 2015 Akanmu D. This is an open-access article distributed under the terms of the Creative Commons Attribution License, which permits unrestricted use, distribution, and reproduction in any medium, provided the original author and source are credited. 


\section{New idioms and idiomatic expressions}

New idioms and idiomatic expressions in Yoruba are quintessentially modern stock expressions, formed in response to the needs of the moment arising as a result of the linguistic constraints of the users which consequently necessitates creation of new words and expressions. They are so called not only because of their complexity which requires the overlapping tendencies of their semantic realizations, but also because of their distinctive difference from old, traditional idioms. As a matter of fact, they straddle metaphor and euphemism and also serve as replication of the established Yorùbá idioms both in form and meaning. They are in spoken and written forms and mainly operate at the lexical and phrasal levels. They are also multi-functional because of their semantic unity. They may equally function as nouns, verbs and adjectives. New idioms and idiomatic expressions are created either through coining, (creating and recreating of new words and expressions) or by investing old words and expressions with new meanings. New idioms are creative, new, strange and fresh by nature. They are not vague expressions and their origins are also known to the users who are always dazzled whenever they come across them in any context.

\section{Existing studies on new idioms and idiomatic expressions}

Like the traditional old idioms where very little efforts were devoted to idiom in passing, few scholars have turned their attention on the study of new idioms and idiomatic expressions in Yoruba. These scholars include Àkànmú and Olátéjú $[1,2]$. In spite of the fact that no direct or specific study of the Yoruba traditional idioms has been carried out in Yoruba studies, we must admit however, that compilation of the old idioms and idiomatic expressions exist. The passing attention being given to Yoruba idioms (new/old) is quite understandable. This is based on the fact that idioms constitute a very crucial aspect of the Yoruba traditional materials and literary resources. By and large, some scholars have described idioms as terms referring to words whose meanings cannot be predicted from the individual elements in them [3-6].

While discussing idioms and coinages, Babalọlá [3] states that with the aid of neologism, idiom can be used for expressing new items and ideas brought into Yorùbá culture by foreigners. His view bears direct relevance to this study in that, neologism is one of the linguistic strategies employed in the formation of new idioms.

Bámgbósé [4] identifies vocabulary coining strategies to include nominalization, explication, semantic extension, and loan words, among others. Through this, the Yorùbá idioms is being expanded. Àkànmú's [1] is not specifically on new idioms but it has some semblance of new idioms in the discussion and examples cited. He employed a sociolinguistic which he referred to as coded language used by certain groups of the Yorùbá society. He cites numerous examples of such expressions that are used in different contexts and discusses their functions in daily activities of the users, even though many of the examples cited as slang are not slang but new idioms used by a considerable number of people.

Owolabi [5], in his doctoral thesis on 'Noun-Noun Constructions in Yoruba' examines morphological composition of idioms and idiomatic expressions in Yoruba. Although, his focus is not directly on idioms, he is of the view that idioms and idiomatic expressions are words whose meanings cannot be predicted from the individual elements in them. The perspective from which he looked at idioms and idiomatic expressions is purely linguistic and not literary as it is in this paper however, his view on literal and underlying meanings of idiom is impressive.

Olátéjú's [2] work is a remarkable contribution on new idioms, their formation and interpretation. He examines new idioms and idiomatic expressions from both the linguistic and literary points of view. He adopted Chomskyan Transformational Generative Grammar (TGG) while stylistic and some sociolinguistic variables were used to bring out aesthetic and communicative potential of the new idioms and idiomatic expressions.

\section{Method of data collection}

Six Yorùbá programmes on 105.6 FM, 107.5, 92.9 FM, 98.5FM, 99.2 FM and 10.55 FM radio stations in Lagos and İbàdàn were purposively selected for having sufficient usage of new idioms and idiomatic expressions. In order to strike a balance, three Yorùbá programmes were selected from different radio stations in Lagos: "Lójú Pópó" on Faaji 105.6 FM, "Omo Ilé Olórin" on 107.5 FM and "Lórí Òdàn on 92.9 FM. Three were also selected from İbàdàn: "Àjàlólerù" on 99.2 FM, "Tìfuntèdò İròyìn" on 105.5 FM and "Nótíkà" on Olúyọlé 99.5 FM respectively [7]. Lagos and İbàdàn were chosen based on the urbanised nature of the two cities and the constant usage of new idioms on the programmes. Data were subjected to pragmatic and stylistic analysis.

\section{Theory of standard language}

The theory of Standard Language was formulated in 1970 by Jan Mukarousky [8] to solve the problem of relationship between Standard Language (SL) and Literary Language (LL). The suitability of this model lies in the fact that it can be used to explain the differential specifica between the language of ordinary usage and literary expressions as well as using it to explain and interpret the deviant and inventive nature of new idioms and idiomatic expressions.

\section{Standard language vs literary language}

According to Mukarovsky [8], Standard Language (SL) is the language of everyday conversation. Its purpose is the understanding between the speaker and the audience with the aim of enhancing effective communication [9]. Language of ordinary discourse is casual and devoid of ornamentation. It is unexamined and uncritical. It does not draw attention to itself or open up provocative questions to the nature of its coding. It is often used in schools, on radio, during political campaigns and preaching. Its priority is effective communication which calls for employment of words and phrases that can be fully comprehended. Therefore, to enhance undistorted communication in Standard Language (SL), language must conform to the entire linguistic norms. Concepts crucial to the Standard Language are 'backgrounding' and authomatization illustrated by the example below:

\section{Làkàsọrọ Literal meaning: corrupt coinage from La casera drink}

Idiomatic: No story/end of discussion

The above expression is a phonological creation from the name of a non-alcoholic drink in circulation all over the country. The expression 'làkàsórọ (la casera) is the standard form that has been foregrounded or de-automatized as 'làkàsórọ'. In other words, it is the artistic form of 'la casera'. There is no expression like 'làkàsórọ' in the standard language. 'Làkàsérà' is automatized and serves as the background from which 'làkàsórọo' is created and used as an idiom. 'Làkàsọogọ' which can be interpreted as 'no story/end of discussion' is made new, thereby becoming element of surprise because it has violated the Yorùbá lexical formation rules. 
Citation: Akanmu D (2015) New Yoruba Idioms and Idiomatic Expressions: A New Mode of Communicating New Concepts and Ideas on Radio. J Mass Communicat Journalism 5: 236. doi:10.4172/2165-7912.1000236

Page 3 of 6

Although, foregrounding is logically prohibited in Standard Language, this is not to say that it is not visible in Standard Language as Mukarovsky indicates its possibility in journalistic language where it can be used as subordinate to communication in order to draw the readers' attention more closely to the issue at hand or the item of information articulated. This must have justified the use of new idioms and idiomatic expressions in routine communicative situation discussed in this paper.

\section{Linguistic strategies involves in the formation of new idioms}

According to Bámgbósé [4], word formation is a universal linguistic concept that is concerned with the study of the patterns on which a language forms new lexical item. As far as formation of new idioms and idiomatic expressions are concerned in this paper, the linguistic strategies involved in their formation include the following:

\section{i) Nominalisation}

Nominalisation is universally known as one of the veritable tools for generating new words in virtually every language. Ruwet [10] views it as the derivation of a noun phrase from an underlying clause or sentence; or the process of forming a noun from other word classes. Below are some examples of new idioms and idiomatic expressions created from the linguistic process of nominalization (Table 1).

\section{ii) Compounding}

Scholars like Ògúnbòwálé, Rowland and Owólabí [5,11,12], have revealed that compounding is a very productive word-formation strategy which entails the combination of two or more independent words to form another word with an entirely different meaning. In other words, two separate words are joined together to produce a single word. New idioms and idiomatic expressions formed through compounding are mostly in form of verb and noun structure $-(\mathrm{Vb}+$ $\mathrm{N} /$ Nominal) or $\left(\mathrm{N}_{1}+\mathrm{N}_{2}\right): \mathrm{Vb}+\mathrm{N}$ (Table 2).

\section{iii) Phonoeasthetic coinages}

Idioms in this category are called phonoaesthetic idioms because they evolve from phonoaesthetic coinages. Idioms of this nature, according to Olátejú [2], refer to words or expressions which by the virtue of their sound composition imitate or suggest their meaning. By nature, they are idiophonic or onomatopoeic and they exhibit

\begin{tabular}{|l|l|l|}
\hline Idioms & Literal meaning & Idiomatic meaning \\
\hline $\begin{array}{l}\text { oní + àsà + kí + àșà } \\
\text { (owner-of-bad-culture) }\end{array}$ & $\begin{array}{l}\text { aláșàkașà } \\
\text { (owner of bad culture) }\end{array}$ & $\begin{array}{l}\text { Onísọkúsọ } \\
\text { (vulgar person/user of } \\
\text { nonsensical language) }\end{array}$ \\
\hline $\begin{array}{l}\text { oní + ebòlò } \\
\text { (owner-of-ebòlò) }\end{array}$ & $\begin{array}{l}\text { Elébòlò } \\
\text { (seller of ebòlò vegetable) }\end{array}$ & A prostitute \\
\hline $\begin{array}{l}\text { má + fo + gọ́tà } \\
\text { (do-not-jump-over-the gutter) }\end{array}$ & mini skirt & indecent dressing \\
\hline
\end{tabular}

Table 1: Nominalisation.

\begin{tabular}{|l|l|l|}
\hline Idioms & Literal meaning & Idiomatic meaning \\
\hline $\begin{array}{l}\text { gbé }+ \text { imú } \\
\text { (carry + nose) }\end{array}$ & $\begin{array}{l}\text { Gbémú } \\
\text { (carry nose) }\end{array}$ & $\begin{array}{l}\text { Yarí } \\
\text { (complain/grumble) }\end{array}$ \\
\hline $\begin{array}{l}\text { wà + wọ́n } \\
\text { (drive + them) }\end{array}$ & $\begin{array}{l}\text { wà wọ́n } \\
\text { (drive them) }\end{array}$ & $\begin{array}{l}\text { parọ́ fún wọn } \\
\text { (lie to them) }\end{array}$ \\
\hline $\mathbf{N}_{1}+\mathbf{N}_{2}$ & an illicit drug like cocain \\
\hline $\begin{array}{l}\text { àtíkè }+ \text { ọlà } \\
\text { (powder of wealth) }\end{array}$ & $\begin{array}{l}\text { Àtíkèọlà } \\
\text { (power of wealth) }\end{array}$ & big boobs \\
\hline $\begin{array}{l}\text { oúnje }+ \text { ọmọ } \\
\text { (child }+ \text { food) }\end{array}$ & Child/infant food formular & \\
\hline
\end{tabular}

Table 2: Compounding

\begin{tabular}{|l|l|l|}
\hline Idioms & Literal meaning & Idiomatic meaning \\
\hline $\begin{array}{l}\text { Gòòbe } \\
\text { Pálasà }\end{array}$ & $\begin{array}{l}\text { A Hausa expression for tomorrow coined } \\
\text { phonoeasthetically to denote a very light and } \\
\text { made-in China products e.g. mobile phones. }\end{array}$ & $\begin{array}{l}\text { confusion/chaos } \\
\text { fake /inferior/substantial }\end{array}$ \\
\hline
\end{tabular}

Table 3: Phonoeasthetic Coinages.

close relationship between the sound component of the word and its meaning and they are mostly one word. The following are examples of such coinages: (Table 3 ).

\section{Analysis of New Yoruba Idioms and Idiomatic Expressions used in Communicating New Concepts and Ideas on Radio}

There are instances where new idioms and idiomatic expressions are employed to express new ideas and concepts that are alien to the Yoruba society, especially innovations in tele communication technology which produced the Global System of Mobile Communication(GSM), infrastructure and a new experience called globalisation. For instance:

(i) -' Àtèjịssẹ" (that-which-is-typed-and-sent) Literal meaning: Press and sent

\section{Idiomatic: Text message}

The above expression is one of the expressions commonly used in GSM and is used widely in communicating messages, especially in routine and official communication. For instance, àtejejísé (text message) is used in a programme called Lójú Pópó (on the road) anchored by Bàsírù Àdìsá on Fàájì 105.6 FM Lagos when one of the eyewitnesses gives traffic situation on the road through a text message thus:

\section{Àtèjísẹ tí a sẹsè gbà láti ọwọo ọmọ Nàijíría rere kan fi \\ yé wa pé súnkẹrẹe-fàkẹrẹre ọkọ wà láti Ajégúnlè \\ sí Mile Two pọ diè nítorí òjò tí ó rọ.}

The text message we have just received from a good citizen of Nigeria informed us that there was a serious traffic jam from Ajégúnlè to Mile Two because of the rain.

Literally, the expression 'Àtejị́se,' which means 'that which is typed, sent and delivered,' is one of the new idioms that are derived through the invention of the GSM. It is another aspect of the wonders of GSM, in which information is sent to the receiver through typing on the mobile phone. The expression is coined based on the descriptive observation of the manner of its operation 'à-tè-jé-ise." (that-which-istyped-sent-and-delivered), which can be interpreted as 'text message'. This interpretation is made possible and clearer not only because of the context of usage as shown above, but also because of the verbs 'te' (print), jiśé (sent or delivered) which has been in existence before now and always used for book publishing in the language.

(ii) -'Yàúyauuù' Literal meaning: Loan word (yahoo) for a site where information is sent and retrieved

\section{Idiomatic: Internet fraudster/user of yahoo}

The above word was used by Babalolá [3], the presenter of a programme called 'Omọ Ilé Olórin' (a child from the house of a musician) on 107.5 FM (Radio Lagos). He narrated his experience about some 'area boys' (social miscreants) who beg for money at a wedding reception. He said:

\section{Èyin yàtọ sáwọn ọmọ yàúyàúù}




\section{Tó ń ya bébà lóní yanya}

You are different from the yahoo boys (Internet fraudsters) who spend extravagantly

In the above, 'yàúyàúu' or 'yàwú-yàwúù' is loaned from 'yahoo', a site for sending and retrieving information on the Internet. It is an idiom because it has been recreated through full reduplication 'yahoo' (yàúyàuù) to mean 'an Internet fraudster'. The word 'yáuù' is similar in sound with its English equivalent 'yahoo'. It also refers to a company or an organization that gives access to people to send and retrieve information from another person. These definitions are attributive of some Internet fraudsters and gamblers, whose appearance look so rough, noisy and rude. Yàúù or Internet fraud is alien to Yorùbá culture. It came with the new invention called 'Internet'. To show that new idioms can be adaptable to things that are alien to Yorùbá culture, expressions such as 'yàúyàúu/'yàwúyàwúù' as featured in the above excerpt, was coined. Now, the expression 'Internet fraud' has no other name in Yorùbá society than yàúyáúu. This assertion is corroborated by the researcher's experience in a conversation between a taxi driver and a passenger at Agbowó in İbàdàn, Oyo State, Nigeria where the taxi driver exhibited his knowledge of the term 'Internet fraud'. He remarked

...gbogbo ònà ló ti bàjẹ tán, àwọn ọmo tó jáde unifásitì kò rísé se. Gbogbo wọn ló di yàhú-yàhúù. Kin ló ń jẹ yàhúyàhúù gan an? Ộnà ijanilólè lórí kọnpútà...

...all the roads are in bad state, the university graduates are unemployed. They have all become Internet fraudsters. What is the exact meaning of Internet fraud? An act of defrauding on the computer...

The use of the expression 'yàuyauuu' in contexts such as the above makes interpretation very easy, This is because, it is through the context that we are able to comprehend the meaning of 'yàúya'uù' as a condemnable act in society which many of the unemployed graduates see as the last option and solution to unemployment. It is also understood by virtually every member of society, both the literates and the illiterates, looking at it from the perspective of a taxi driver who was believed to have known nothing about the operation of the Internet. He was able to express himself in a context such as the above. Yahoo/ yahoo-yahoo is also used in another context to mean different things in routine communication. For example, on 92.9 FM, İkòyí, Babalolá, a presenter of a programme called 'Lórí Òdàn' informed his audience thus:

...Yàúù nikan ni ẹ lè lò lati fi bá wa sọrọ lórí êro ayélujára. Kí ètò yií tó parí a ó fun yín ní àdiresesi yàúù wa.

...It is only Yahoo that you can use to communicate with us on the Internet. Before the end of this programme we shall give you our Yahoo address.

In the excerpt above, yàuù, which is a phonoaesthetic coinage is used as channel of communication on the Internet. The presenters' use of 'only yahoo...', suggests that there are other channels or means of communication on the Internet where user can send and retrieve information. Contexts such as the above facilitate easy and clear comprehension of the expression Yahoo to mean a channel for sending and retrieving information on the net. Other examples in this category include: itàkùn MTN (MTN network), itàkùn Glo (Globacom network), itàkùn Etisalat (Etisalat network), èrọ ibánisọrọ alágbèéká (mobile phone) etc. Apart from those that are used in the context of globalization or mobile phoning, there are many other new idiomatic expressions used for different purposes. For instance, consider the examples below where new idioms are used for both communication and entertainment:

\section{(iii) - 'İtàkùn Airtel' Literal meaning: Airtel's aerial root}

Idiomatic: Airtel network/mobile line

This expression was used for advertisement on a programme called 'Kókó Inú İwé İròyin' on 92.9 FM thus:

...Dara pọ mợàwọn tí ó ń lo Itàkùn Airtel 'láti fún ọníànfààní láti jẹ ọkan nínú àwọn olóríire èèyàn tí yóo jẹ míliọnù kan náirà fún ogớta ojó...

...Join the subscribers who are using Airtel Network to give you a chance to be one of the successful persons that are going to win a million naira for fifty days...

The expression İtàkùn Airtel is a combination of the Yorùbá 'ìtàkùn' (aerial root) and English expression 'Airtel' (company's name) interpreted connotatively to mean Airtel network or Airtel Mobile line given to all the subscribers ${ }^{7}$ Here, the use of itàkùn is cultural based on semantic transfer. Therefore, interpretation can only be meaningful when the socio-cultural context of this nature is considered. Culturally speaking, İtakkùn (aerial root), as used in the text is based on the observation of the interconnectivity nature and function of itàkùn spreading from its own branch to the branches of the other trees around.

\section{(iv) - 'İtàkùn àgbáyé' Literal meaning: Global Aerial Root}

\section{Idiomatic: The Internet}

İtàkùn àgbáyé', which literally means 'global aerial root,' is another idiomatic expression whose use is motivated by recourse to culture. It is used frequently in routine communication like the following:

...Gbónmi sí i omi ò tó o tí ó ń selè láàrin Ààre Goodluck Jonathan àti Ààre àná, Olúségun Obásanjọ ti di ohun tí àwọn ọmo Nàijírià ń gbà bi ẹni gba igbá ọtí lóri èrọ 'İtàkùn Àgbáyé'.

\section{(Aláròyé, July 18, 2013)}

...The rift between President Goodluck Jonathan and the former president, Olúségun Obásanjo', is now a talk of the town by Nigerians on the Internet.

The expression İtàkùn àgbáyé (global aerial root) which can be interpreted as the Internet was used by the Aláròyé newspapers to create awareness that all is not well with the incumbent president and his predecessor. 'İtàkùn' (aerial root) was used here in relation to the interconnectivity of the Internet system which makes it possible for any user to connect with the other parts of the world from his cocoon in a way similar to the aerial root of any tree connecting with others around it. One needs the cultural knowledge of the nature and function of 'itakun' (aerial root) in the farm to arrive at an acceptable meaning of the expression İtàkùn àgbáyé' (The Internet).

(v) - Ėrọ a-yára-bí-àsáa Literal Meaning: a system that is clever like hawk

\section{Idiomatic Meaning: Computer set}

This expression, 'érọ- $a$-yára-bí- àsáa", is also a common idiomatic expression whose interpretation is culture based. It is used in routine communication thus: 
A dúpé lớwọ' ilé iṣé Multy Link fún ẹrọ 'ayára bí àsá' tí wọn fún wa láti fún àwon olùgbơ' wa tí ó gba àwon ibeeèrè wa lórí ètò yií. ('Àjàlolẹrù FM, 99.2 İ̀àdàn)

We thank the Multy Link Company for the computer set given to us for our audience who answered our questions on this programme.

The above expression, 'érọ a yára bí àsá' (a system-that-is-cleverlike-hawk) was used by Taiwo Fakorede and Akinwumi Akintade on 'Amúlùúdún' FM, 99.2 while anchoring a programme called 'Ájàlólerù'. It was used to show appreciation for a kind gesture extended to them on the programme. The expression whose interpretation lies in the description of the nature and attribute of an hawk (clever) in Yoruba culture was created using nominalisation 'a + yára + bí + àsá' (that - which - is - clever - like - hawk) and conveyed through semantic transfer.

(vi) - 'Okộ Róobonmi/ayẹta/rótadànù Literal meaning: A vehicle that consumes bullet Idiomatic: Bulletproof car

The above expression, 'ọkọ rọọnmi' pervades every aspect of Nigeria's socio-political live in the recent time, especially when a serving minister of the Federal Republic of Nigeria was indicted for buying bullet-proof cars, as expressed by Adébáyọ Fálekè on a programme called 'Tìfuntẹdọ İròyin' on 10.55 FM:

...İwé iròyin Punch ní ọkọ rọbọnmi méji tí wọn rà fún alákòóso igbòkègbodò ọọ ò furufú lóríle èdè yií Stella Odua, wí pé ọkọòkan ọkọ yií wớn ju ti ọba ilú òyinbó lọ.

...The Punch newspapers said that each of the two bullet-proof cars purchased for the Nigerian minister of Aviation, Stella Odua, was more expensive than that of queen Elizabeth of England.

Other idioms/idiomatic expressions used to refer to a bullet-proof car, apart from ọọ rọ́bọnmi include ọkọ ayẹta, ọkọ agbọ́ta dànù or okọ rotadanù. All these idiomatic expressions literally refer to 'vehicle that consumes bullet', and can be interpreted as 'bulletproof vehicle'. Although it is alien to Yoruba culture because the invention of such a car is foreign, it becomes meaningful through the above context, especially when one notes that in Yoruba culture, it is possible to shoot somebody with a gun and the bullet is rendered ineffective. There are magical spells and charms in the culture that make a person bulletproof. It is, therefore, not strange, to create an idiom to express this modern invention.

\section{Findings}

In this paper, we discovered that new idioms and idiomatic expressions were found to be used to express new concept and ideas. These new concepts and ideas were peculiar to the electronic media especially, radio and was in the context of mobile phoning/Internet and other form of technological sophistication. Examples of unique issues that were expressed include 'èrọ- a-yára-bí-àsá' (a system that is clever like hawk) for computer, 'yàuyàuuu' (yahoo) for internet fraud, ìtàkùn àgbáyé (global aerial root) for the Internet, 'àtejísé' (text message) and 'oko-ọ-robọn-mi' (bulletproof vehicle). The paper also revealed various linguistic strategies involved in the creation of new idioms and idiomatic expression. These include neologism through prefixation and nominalisation, compounding and phonoeasthetic coinages. Some of this strategies are conveyed through metaphorisation. Through these strategies, new terms, concepts, thought and ideas relating to new development in transportation, politics, telecommunication, science and technology are freely expressed on radio. Nominalisation and compounding occurred in virtually all the stations; the former was contextualised in advertisement (ẹ̀rọ-a-yára-bí-àsá) and fraud/ embezzlement (ọkọ-ọ-rọ́-ibọn-mì) while the later was in the context of advertisement (itàkùn étéelì), political rift/power play politics (ìtàkùn àgbáyé,) and executive class (ọbọ̀kún ọlộyé). Phonoeasthetic coinages occurred in the contexts of fraud and information (yàuyàuù). The use of linguistic strategies in this regards revealed that a considerable numbers of new idioms situated in different contexts - social economy, political and cultural have entered into the lexicon of the language because of their frequent uses in routine communication on radio. They have become so integrated and attenuated to the extent that many of them no longer pose serious problems before they can be meaningfully understood or interpreted. Few examples of such idioms that have become household expressions include - itakun agbaye (Internet), afara oloke (over-head bridge), atejise (text messages) etc.

\section{Conclusion}

New idioms and idiomatic expressions are quintessentially unique expressions, mostly used in a special and peculiar way when viewed from communicative and stylistic perspective. These expressions are new types or different shades of the Yoruba traditional idioms used as a tools in the hands of artistes, poets, politicians, bus conductors, artisans, musicians, students, journalists and broadcasters who have the urgent desire to educate Nigerians about new developments in science and technology as well as telecommunication. New idioms and idiomatic expressions are used when users are incapacitated by certain linguistic constraints imposed on them by the Yoruba language, especially difficulty in getting appropriate lexical items and terms for the expression of their ideas. They are new mode of communication used to express socioeconomic, traditional and emotive issues in Yoruba routine communication, occurred in mediated and non mediated contexts and are conveyed through metaphorisations. These idioms reflect dynamism and modernity-constrained stylistic choices in Yoruba discourses. We therefore, conclude that contrary to the opinions expressed in the editorial comments of the Sunday Sun of March 28, 2004 that new words, concepts and ideas emanating from science and technology can hardly be captured by the lexis and structure of our indigenous languages, this paper has proved that such opinions are baseless and have been debunked. From the foregoing, especially the linguistic strategies involved in the formation of the new idioms and idiomatic expressions, it is clear that the Yorùbá language has the mechanism to cope with such communicative exigencies.

\section{References}

1. Àkànmú D (2003) "Àșàdídá İgbàlódé àti Ì̀ò wọn fún İdàgbàsókè Ėdè Yorùbá". Lángbásà 10: 42-53.

2. Olátẹjú MOA (2005) In Yorùbá Gentivities, Fiction, Language and Song edited by T. Fálọlá and Ann Geneova, 273-287.

3. Babalọlá N (1972) The Growth of the Yorùbá Language: Problems encountered and Solutions.

4. Bámgbósé A (1975) Relative Clauses and Nominalized Sentences in Yorùbá.

5. Owólabí K (1976) "Noun-noun Constructions in Yorùbá Language. University of Ibadan, İbàdàn.

6. Awóbùlúyì O (1992) Lexical Expansion in Yorùbá: Techniques and Principles Research in Yorùbá Language and Literature. Burbark: 2: 14-91.

7. A Structuralist Study of the Sound patterns in Yorùbá Poetic Discourse. University of Ibadan, İbàdàn.

8. Mukarousky J (1970) Standard Language and Poetic Language. Linguistic and Literary Style, Massachusett. 
Citation: Akanmu D (2015) New Yoruba Idioms and Idiomatic Expressions: A New Mode of Communicating New Concepts and Ideas on Radio. J Mass Communicat Journalism 5: 236. doi:10.4172/2165-7912.1000236

Page 6 of 6

9. Crystal D (1997) The Cambridge Encyclopedia of Language. Cambridge University Press, USA.

10. Ruwet (1973) An Introduction to Generative Grammar. Amsterdam.
11. Ògúnbọ̀wálé J (1967) Essentials of the Yorùbá Language. İbàdàn: İbàdàn University Press.

12. Rowland (1969) Teach Yourself Yoruba. London: English University Press 